(๑) SW\&E, 2018

Dariya Velykzhanina,

post-graduate student,

Department of Pedagogy and

Pedagogical Excellence,

Melitopol State Pedagogical

University named after Bogdan

Khmelnytsky,

Melitopol, Zaporozhye region,

Ukraine,

darya.velik@ukr.net

\section{Дар'я Великжаніна, \\ Аспірант,}

кафедра педагогіки і педагогічної

майстерності,

Мелітопольський державний

педагогічний університет

імені Богдана Хмельницького,

м. Мелітополь, Запорізька

область, Україна

УДК 373.5.011.3-052:005.336.2:36(045)

DOI: $10.25128 / 2520-6230.18 .1 .9$

Article history:

Received: Febuary 28, 2018

1st Revision: March 20, 2018

Accepted: March 31, 2018

\section{ЖИТТЕВА КОМПЕТЕНТНІСТЬ ПІДЛІТКІВ: СУТНІСТЬ ТА ОСОБЛИВОСТІ ФОРМУВАННЯ В УМОВАХ ЗАГАЛЬНООСВІТНЬОГО НАВЧАЛЬНОГО ЗАКЛАДУ}

АНОТАЦІЯ. У статті висвітлено пріоритетність реалізації та концептуальні ідеї компетентнісного підходу до освіти в Україні. Обгрунтовано актуальність формування життєвої компетентності підростаючого покоління в умовах сучасності. Результатом наукових розвідок виступає спроба розкрити сутність дефініції «життєва компетентність підлітків» як усвідомленого ними комплексу особистісних характеристик й здатностей щодо вияву відповідальної, самостійної, соціально зрілої поведінки в межах свого вікового розвитку; визначення першочергових та другорядних життєвих цілей $\mathrm{i}$ перспектив 3 розробкою варіативних планів їх досягнення; провадження власної життєдіяльності в контексті безперервного самовдосконалення як ключового сегменту особистісного розвитку. Окреслено соціально-педагогічний потенціал загальноосвітнього навчального закладу щодо створення комфортних умов для розвитку й становлення особистості кожного учня, формування ключових компетентностей для життя підлітків. Визначено необхідність концентрації педагогічних зусиль й організації соціально-педагогічної роботи 3 підлітками у школі за такими напрямками, як: сприяння їх позитивній соціалізації; формування потреби у безперервній самоосвіті, самореалізації в різних сферах життя, умінь обирати цілі, розробляти плани їх досягнення, здатності вирішувати життєві задачі різної складності; розвиток критичного мислення, самостійності, конкурентоспроможності, соціальної активності, ключових життєвих компетентностей. Зосереджено увагу на потребі професійної підготовки педагогічних кадрів, зокрема соціальних педагогів, до роботи 3 підлітками в умовах орієнтації сучасної школи на розвиток життєвої компетентності особистості дитини. Виділено технології соціально-педагогічної діяльності 3 підлітками в школі, які сприятимуть як формуванню життєвої компетентності молодого покоління, так і успішній реалізації компетентнісного підходу в освіті в цілому.

Ключові слова: компетентність; життєва компетентність; підліток; загальноосвітній навчальний заклад; компетентнісний підхід до освіти; соціально-педагогічна діяльність; професійна компетентність соціальних педагогів. 


\section{Вступ}

Пріоритети сучасної української освіти, яка на часі перебуває у стадії докорінного й комплексного реформування всіх іiі рівнів, зосереджуються у площині інноваційності, індивідуалізації, гуманізації й демократичності навчання і виховання підростаючого покоління. Переорієнтація сучасної школи з надання дитині лише фундаментального знання на багатогранний розвиток особистості, формування життєво компетентної людини та конкурентоспроможного члена суспільства сьогодні $\epsilon$ не далекою перспективою, а необхідністю сьогодення, потребою мінливих умов життя у сучасному соціумі, стрімко прогресуючих сфер науки та технологій.

Тому розбудова оновленої системи освіти в Україні базується на засадах компетентнісного підходу до навчання і виховання учнів. Такий підхід до освіти передбачає опанування дітьми не лише дисциплінарними (галузевими) компетенціями, а й ключовими компетенціями для життя: умінням вчитися впродовж життя, спілкуватися державною, рідною та іноземними мовами, оволодіння базовими компетенціями в галузі природничих наук та щодо інформаційно-цифрової, комунікаційної, соціальної і громадянської, загальнокультурної, підприємницької діяльності, а також набуття математичної, екологічної, здоров’язбережувальної грамотності (Концепції реалізації державної політики у сфері реформування загальної середньої освіти «Нова українська школа» на період до 2029 року, 2016).

Компетентнісний підхід до освіти надає можливість забезпечити в системі навчання й виховання реалізацію індивідуальних потреб дитини, сприяти гармонійному розвитку iї особистості, гнучко у часі і просторі підвищувати компетентності дитини 3 різних напрямів освітньої підготовки та в різних життєвих ситуаціях. Такий підхід дає змогу розширити спектр засобів i технологій самоосвіти, самовизначення, самоствердження і самовдосконалення дитини, надати їй можливість знайти своє місце в сучасному суспільстві (Нечипоренко В.В., 2013, с. 97). Перехід від знаннєвої школи до школи компетентностей забезпечить реалізацію головної мети освіти, яка полягає у всебічному розвитку людини як особистості і найвищої цінності суспільства, розвитку іiі талантів і здібностей, формування цінностей i необхідних для успішної самореалізації компетентностей, виховання відповідальних громадян, які здатні до свідомого вибору та спрямування своєї діяльності на користь іншим людям і суспільству (Закон України «Про освіту», 2017).

Формування життєвої компетентності дітей, яка консолідує накопичені знання, сформовані здатності, особистісні якості й власний життєвий досвід людини, за таких умов виступає інтегруючим завданням реалізації концептуальних ідей оновленої системи української освіти.

Життєва компетентність людини, в свою чергу, полягає у іï спроможності вирішувати життєві проблеми самостійно; у вмінні використовувати знання й досвід у різних життєвих обставинах; у здатності визначення цілей та засобів їх досягнення, окреслення життєвих орієнтирів й вибору сфер та меж особистісної самореалізації; у здатності спрямовувати внутрішні ресурси на самопізнання, саморозвиток та самовдосконалення, на розкриття творчого потенціалу, на продуктивну взаємодію 3 
оточуючими. Особливого значення ці здатності людини набувають у підлітковому віці, який характеризується прагненням особистості підлітка до незалежності, саморозуміння, соціальної ідентифікації та прийняття, пошуку індивідуальної моделі поведінки, життєвих авторитетів й поважного ставлення до власних переконань та ідей.

Сучасна загальноосвітня школа має виступати школою життєвої компетентності для підлітків, освітньою платформою для набуття ними компетентностей, засвоєння досвіду їх застосування в різних сферах життєдіяльності та збагачення соціальної життєвої практики. У процесі навчання та виховання, у взаємодії з іншими людьми, засвоєння загальнолюдських цінностей відбувається становлення особистості підлітка, тому доцільним орієнтиром шкільної освіти $€$ врахування індивідуальних особливостей, розвиток здібностей й компетентностей підлітків, що сприятиме їх успішній соціалізації та самореалізації. Розвиток життєвої компетентності дітей входить до кола професійної діяльності соціального педагога у школі, який зосереджує свої професійні знання і уміння на створенні комфортних умов для всебічного розвитку дітей.

Ефективність процесу формування життєвої компетентності підлітків у загальноосвітньому навчальному закладі залежить від багатьох факторів: доброзичливого ставлення школи до дитини; розуміння актуальних освітніх завдань і концептуальних положень життєвої компетентності як результату навчання і виховання; чітко організованої соціально-педагогічної діяльності щодо підтримки й спрямування учнів на шляху їх життєвого становлення; конструктивної взаємодії педагогів, учнів та їх батьків; провадження освітньої політики «для дитини, разом із дитиною» у школі; надання навчальним закладом підростаючому поколінню якісних освітніх послуг та компетентностей для життя. Головним 3 них вважаємо саме розуміння всіма учасниками освітнього процесу сутності життєвої компетентності та іiі характерних ознак у підлітковому віці, володіння соціально-педагогічними механізмами іiі формування в процесі шкільного навчання та виховання.

\section{Аналіз останніх публікацій}

Питання визначення сутності життєвої компетентності особистості, особливостей іiі розвитку у дітей, організації педагогічної діяльності з дітьми щодо ix життєвого становлення були предметом досліджень вітчизняних вчених П. Горностая, І. Срмакова, Ю. Кулюткіна, Н. Лобанової, В. Ляшенка, Л. Макаренко, А. Маркової, Л. Мітіної, Г. Несен, В. Нечипоренко, В. Нищети, О. Савченко, Н. Остапчук, Є. Павлютенкова, О. Пометун, Д. Пузікова, І. Родигіної, Г. Сазоненко, Л. Сохань, М. Степаненка, Г. Сухобської, В. Циби, I. Ящук та ін. Однак потребують деталізації сутність й характерні ознаки життєвої компетентності підлітків, як вразливої до суспільних впливів категорії дітей, а також специфіка її формування в умовах загальноосвітньої школи.

Метою статті $€$ визначення сутності життєвої компетентності підлітків та особливостей іï формування в умовах загальноосвітньої школи. 
Завдання статті передбачають:

- аналіз сутності дефініцій «компетентність», «життєва компетентність» та, на їх основі, надання характеристики життєвої компетентності підлітків;

- визначення соціально-педагогічного потенціалу загальноосвітньої

школи у формуванні життєвої компетентності підростаючого покоління;

- окреслення технологій соціально-педагогічної діяльності в школі щодо формування життєвої компетентності підлітків.

Методологією дослідження виступають загальнонаукові методи аналізу, синтезу, узагальнення й систематизації науково-практичного знання 3 питань соціально-педагогічної роботи з дітьми у школі.

\section{Основна частина}

Розумінню сутності життєвої компетентності підлітків передує аналіз дефініцій «компетентність» та «життєва компетентність». Законом України «Про освіту», що вступив у дію 29 вересня 2017 року, компетентність визначається як динамічна комбінація знань, способів мислення, поглядів, цінностей, навичок, умінь, інших особистісних якостей, що визначає здатність особи успішно провадити професійну та (або) подальшу навчальну діяльність (Закон України «Про освіту», 2017). Компетентність особистості трактується i як поєднання знань, умінь, цінностей і ставлень, що застосовуються нею для рішення завдань повсякденного життя. Вона також характеризується як інтегрована категорія, що виражає сформовану насамперед засобами освіти здатність індивіда успішно розв'язувати загальні і специфічні проблеми як у трудовій діяльності в якості фахівців, так і в суспільному житті в якості громадян. Компетентність виступає інтегральною характеристикою особи, яка складається $з$ окремих компетенцій. Компетентність характеризує ту чи іншу реалізаційну здатність людини - спроможність до самореалізації, реалізації життєвих цілей, розв'язання певних завдань (Варецька O. B., 2014, c.118 - 126)

Компетентність $€$ результатом набуття компетенцій. В такому розумінні компетенція - це сукупність взаємопов'язаних якостей особистості (знань, умінь, навичок, способів діяльності), які є заданими до відповідного кола предметів і процесів та необхідними для якісної продуктивної дії по відношенню до них; а компетентність, в свою чергу, є сформованою особистісною якістю, особистісним ставленням до предмету діяльності та іï результатом (Хуторський А. В., 2002, с. 135 - 157).

Компетентність розглядається і як здатність до суспільно-значущої, соціально корисної діяльності на основі когнітивного надбання й особистісного життєвого досвіду. Компетентність характеризується знанням і здатностями людини для продуктивної діяльності, розумінням значення знаннєвого ресурсу в життєвих реаліях, спроможністю творчо вирішувати завдання різної складності, сформованістю ціннісних орієнтацій, які визначають мотиви й стиль життєдіяльності особистості, іï прагнення до самовдосконалення й саморозвитку.

Життєву компетентність, в свою чергу, розглядають як інтегральний показник здатності і готовності особистості до успішної самореалізації та життєпобудови по закінченні навчального закладу. Так, науковці I. Срмаков, Л. Сохань, Л. Несен 
життєву компетентність розуміють як знання, вміння, життєвий досвід особистості, іiі життєтворчі здатності, необхідні для розв'язання життєвих завдань і продуктивного здійснення життя як індивідуального життєвого проекту (Сохань Л. В., Єрмаков І. Г., Несен Л. М., 2003, с. 11).

Життєва компетентність передбачає компетентне ставлення особистості до життя - потребу в самопізнанні, саморозумінні, саморегуляції в різних видах діяльності, а також свідоме і відповідальне ставлення до виконання особистістю іiі життєвих і соціальних ролей (Срмаков І. Г., Пузіков Д. О., 2005, с. 31).

На думку І. Срмакова, життєва компетентність - це передусім здатність особистості вирішувати проблеми в усіх сферах життєдіяльності, виконувати життєві й соціальні ролі, які грунтуються на життєтворчих знаннях, уміннях і навичках, життєвих досягненнях. Вчений зазначає, що життєва компетентність передбачає здатність особистості не лише до необхідних вчинків за певних обставин, які створені або нав'язані людині культурними та суспільно-історичними умовами ії життєдіяльності. Вона також зумовлює здатність особистості визначати, наближати та здійснювати життєві події, які не могли б відбутися без iї активного втручання. Життєва компетентність грунтується на життєтворчих знаннях, знаннях законів, правил, норм життя, які допомагають усвідомити масштаби власної особистості, психофізіологічні ресурси та перспективи розвитку (Срмаков I. Г., 2005, с. 265).

Життєва компетентність людини полягає у іï спроможності вирішувати життєві проблеми самостійно; у вмінні використовувати накопичений досвід у різних життєвих обставинах, зокрема кризових ситуаціях; у здатності приймати рішення та діяти у напрямку їх реалізації; у визначенні цілей та засобів їх досягнення; у спрямуванні внутрішніх сил на самопізнання, саморозвиток та самовдосконалення, на розкриття творчого потенціалу, а також на дію в інтересах суспільства; у побудові стратегій розвитку власного життя; у здатності до об'єктивної оцінки сфер та меж поширення своєї життєвої активності; у здатності продуктивної взаємодії та осмисленого розв’ язання міжособистісних суперечностей.

Як і кожне складне й багатогранне явище життєва компетентність потребує власної структури. Л. Сохань подає таку структуру життєвої компетентності: 1) знання; 2) уміння й навички (теоретичні знання включають наукові (знання про світ, законів життя, про себе) та життєву мудрість, яка разом з нормами поведінки складає також і практичні знання та вміння й навички); 3) життєтворчі здібності (аналітичні, поведінкові, прогностичні); 4) життєвий досвід (складається 3 усвідомленого та неусвідомленого індивідуального досвіду й творчого використання й наслідування досвіду інших осіб); 5) життєві досягнення (особисте щастя, соціальний статус, самореалізація) (Сохань Л. В., Срмаков І. Г., Несен Л. М., 2003, с. 10).

В. Нищета, спираючись на узагальнені постулати теоретичних досліджень життєвої компетентності, виокремлює такі їі компоненти: 1) компетентності відносно себе як особистості, як суб’єкта життєдіяльності («Я-концепція», ціннісні орієнтації, якості емоційно-вольової сфери); 2) компетентності відносно взаємодії з іншими людьми (комунікативна, полікультурна, конфліктна компетнтності); 3) компетентності відносно діяльності в усіх іï видах і формах (функціональна та мотиваційнаї компетентності, проективна культура). Також, на думку вченого, життєва компетентність включає в себе здатність до творчого перетворення себе, 
емпатію, відповідальність, комунікабельність, рольову поведінку, здатність до співпраці, самостійність, критичне, стратегічне та прогностичне мислення, креативні якості і є мистецтвом жити, запорукою життєстійкості та життєздатності особистості (Нищета В. А., 2008, с. 257-264).

Інтегрованим змістом поняття життєвої компетентності людини є широкий спектр іï соціальних й комунікативних умінь, заснованих на знаннях, досвіді, цінностях, які були отримані в процесі навчання; здатність застосовувати знання, уміння й досвід відповідно до життєвої ситуації; здатність до самовдосконалення, до оновлення та отримання нових знань та умінь (Удод О. А., Бондар В. I., 2010, с. 66-67).

Сутнісна характеристика життєвої компетентності підлітків не можлива не лише без розуміння концепту iї фундаментальних дефініцій та структури, а й без усвідомлення природи підлітків, ситуації їх специфічного психофізіологічного та соціального розвитку, окреслення сучасних тенденцій розвитку підліткового середовища.

Внутрішні ресурси, особистісні характеристики та активність, задатки та здібності дитини здійснюють безпосередній вплив на набуття нею життєвої компетентності. Саме на свій внутрішній потенціал, власні особистісні можливості, соціальну активність та значущість звертає увагу підліток, прагнучи до самопізнання та самоствердження. Підліток із соціально-психологічної точки зору характеризується прагненням до самостійності у прийнятті рішень стосовно самого себе, почуттям дорослості, бажанням пізнати себе, відчути свою значимість у родині та серед однолітків, бути компетентним у різних сферах життя. Дуже часто власні цінності підлітка протиставляються цінностям родини чи однолітків. Коло проблем дітей підліткового віку включає конфлікти з батьками, демонстрацію негативного ставлення до них, індивідуалізацію, любов, пошук авторитетів тощо. Підлітковому віку властиві сором'язливість або демонстративна поведінка, небажання приймати на себе серйозні зобов'язання, притаманне відчуття, що суспільство їх не розуміє й не приймає. Підліток, позиціонуючи себе як доросла людина і незалежна особистість, на відміну такої ще не має сталих соціальних мотивів поведінки, достатнього життєвого досвіду для самостійного вирішення різних життєвих задач, чітко сформованої картини світу та морально-ціннісного особистісного фундаменту (Кутішенко В. П., 2010, с. 52).

Труднощі соціалізації в підлітковий період також пов’язані з трьома головними обставинами: розбіжністю між високим рівнем домагань підлітків і низьким соціальним статусом, який заданий їх віком; розбіжністю між старим стилем батьківства, орієнтованого на те, що для матері син і дочка завжди залишається дитиною, i новими потенційними можливостями підлітків, заданих їх психофізіологічним дорослішанням; протиріччям між посиленою орієнтацією на самостійність і зростаючою залежністю від думки і поведінки однолітків (Лещук Г., 2014, c. 77).

Крім того, соціально-психологічна ситуація розвитку в підлітковому віці містить перехід від дитинства до самостійності й відповідальної дорослості. У підлітка формується індивідуальний стиль поведінки, розумової та комунікативної діяльності. Вразливість підлітків, загострене почуття справедливості та іï прагнення, бажання активної дії - також характерна ознака підліткового віку. Відсутність можливості цього важливого аспекту у зростанні дитини як 
особистості може спричинити деструктивну, демонстративну поведінку, пошук підтримки у віртуальному світі або різних неформальних угрупованнях (Прашко О. В., 2013, с. $23-27)$.

Орієнтуючись на специфічні особливості підліткового періоду, життєву компетентність підлітків можна означити як усвідомлений комплекс особистісних характеристик й здатностей щодо вияву відповідальної, самостійної й соціально зрілої поведінки в межах свого вікового розвитку; визначення першочергових та другорядних життєвих цілей i перспектив 3 розробкою варіативних планів їх досягнення; провадження власної життєдіяльності в контексті безперервного самовдосконалення як ключового сегменту особистісного розвитку в цілому.

Ознаками життєвої компетентності підлітків можна вважати: сприйняття школи не лише як бази теоретичної підготовки до життя, а розуміти ії як місце включення до соціально-життєвої практики; самостійність у вирішені життєвих труднощів, визначенні життєвих цілей та планів, побудові стратегій їх реалізації; орієнтацію у мінливому соціальному просторі та адаптація до сучасних вимог ефективної життєдіяльності; толерантність, мобільність, конкурентоспроможність; орієнтацію у насиченому інформаційному просторі; продуктивність комунікаційних зв'язків; креативність, критичне мислення, баланс між соціально-корисною поведінкою і засобами самореалізації підлітка.

Навчитись визначати цілі власного життя, застосовувати творчий підхід до їх досягнення, розбудовувати власну життєву ціннісно-нормативну картину світу, розвивати свою індивідуальність, вирішувати складні життєві завдання, набувати і виконувати соціальні ролі дитина може у процесі навчання, виховання та соціалізації. Максимальне включення дитини до цих процесів відбувається в період ії шкільного життя, де школа виступає як соціальна інституція, яка має забезпечити не лише набуття дитиною фундаментальних знань, умінь та навичок, а й створити сприятливі умови для розвитку життєвої компетентності особистості. Перед загальноосвітньою школою постає завдання не стільки дати дитині систему галузевих знань, скільки у доступній формі розкрити перед нею науку життя - сформувати практичні й життєво необхідні вміння, навчити орієнтуватись у мінливих умовах життя, знаходити своє місце серед інших, відчувати межу припустимої поведінки, ініціювати доброчинність. Саме шкільний простір демонструє дитині палітру можливостей розвитку всіх сфер іiі життєдіяльності для забезпечення належної соціалізації та самореалізації, формування життєвої компетентності. Сучасна школа - це школа життєтворчості особистості. Це школа, у якій реалізуються ідеї проектної, особистісно зорієнтованої педагогіки (Срмаков І. Г., 2005, с. 29).

Ключові компетентності особистості потрібно формувати у школі за допомогою спеціально підготовленого змісту, технологій і розвивально збагаченого середовища, яке має такі ознаки: відкритість, цілісність, емоційна комфортність, суб’ єктність навчальної взаємодії (Савченко О., 2011, с. 4 - 8).

Ефективна соціально-педагогічна діяльність у загальноосвітній школі в напрямку розвитку життєвої компетентності дітей даної вікової категорії змушує педагогів використовувати соціально-педагогічний потенціал школи у провадженні своєї професійної діяльності 3 підлітками, розробляти та запроваджувати інноваційні навчально-виховні технології, методи та форми 
соціально-педагогічної роботи, які мають активізувати учнів на саморозвиток, творчий підхід до вирішення життєвих задач, набуття ключових життєвих компетентностей.

Загальноосвітня школа сьогодні може характеризуватися такими потенційними можливостями в напрямку формування життєвої компетентності підлітків, як: позиціонування навчального закладу як простору життя дитини, де вона не готується до життя, а повноцінно живе, і тому вся діяльність навчального закладу вибудовується так, щоб сприяти становленню особистості підлітка як творця і проектувальника власного життя, гармонізації і гуманізації відносин між учнями та педагогами, школою й родиною; реалізація принципів компетентнісного підходу до освіти, створення умов для їх успішної життєдіяльності в соціумі; сформованість на високому рівні життєвої компетентності соціальних педагогів, їх готовність до здійснення соціальнопедагогічної діяльності з підлітками в напрямку їх соціалізації та особистісного становлення; колектив однолітків, який виступає каталізатором особистісного розвитку підлітка паралельно із здійсненням його намірів щодо продуктивної взаємодії та виконання значущих соціальних ролей; орієнтація педагогів на впровадження у навчально-виховний процес технологій життєтворчості, які покликані забезпечити розвиток і реалізацію здатності особистості підлітка самостійно, творчо визначати і здійснювати власне життя, визначати цілі, складати плани їх реалізації; включення дитини у процес розв'язання життєвих ситуацій різної складності, які моделюються соціальним педагогом 3 метою формування відповідних соціальних, психологічних, життєвих умінь та досвіду, або виникають стихійно.

Особливостями формування життєвої компетентності підлітків у загальноосвітній школі можна вважати домінуючу роль у цьому процесі соціального педагога як фахівця. Реалізуючи у своїй професійній діяльності навчальну, виховну, розвиваючу, соціально-захисну, діагностичну, прогностичну, консультативну, організаційну та посередницьку функції соціальний педагог, 3 обов'язковим орієнтиром на особливості соціально-психологічного розвитку особистості підлітка, сприяє його особистісному становленню, розвитку життєвої компетентності та успішній соціалізації (Сейко Н. А., 2002, с. 64 - 66).

Освіта має бути зрозумілою для підлітка, він має усвідомлювати іiі конкретні задачі й сфери застосування отриманого знання. У роботі з підлітками важливо спиратися на сучасні, соціально активні, креативні, індивідуалізовані засоби їх життєвого становлення, розвитку ключових компетентностей для життя.

Соціально-педагогічну роботу з підлітками у школі доцільно здійснювати за такими напрямками, як: сприяння позитивній соціалізації учнів; формування потреби у безперервній самоосвіті, самореалізації в різних сферах життя, умінь обирати цілі, розробляти плани їх досягнення, здатності вирішувати життєві задачі різної складності; розвиток критичного мислення, самостійності, конкурентоспроможності, соціальної активності, ключових життєвих компетентностей.

Від соціальних педагогів значною мірою залежить мотиваційний, освітньокультурний, соціально-комунікативний, професійно орієнтований аспекти 
компетентнісного становлення школярів, розвиток у них здатності акумулювати власні особистісні ресурси та взаємодіяти 3 оточуючими для досягнення поставлених життєвих цілей. Соціальний педагог має не лише володіти знаннями щодо соціально-психологічних особливостей розвитку підлітків, а й розуміти, чим живе сучасна дитина, чим цікавиться, яке середовище іiі оточує і впливає на іiі особистісний розвиток, які питання iіi турбують і які ризики опиняться на іiі шляху. Важливо вміти знайти підхід до сучасного підлітка та залучити його до самопізнання та саморозвитку, до набуття життєвої компетентності. Соціальнопедагогічна робота з підлітками змушує соціального педагога паралельно із професійним знанням виявляти і власну життєву компетентність у багатогранних буденних питаннях, виявляти бажання, готовність і здатність до саморозвитку в особистісному та професійному напрямку, готовність до дії у мінливих (складних, кризових) обставинах, до прийняття нестандартних рішень, до вибору доцільних засобів професійного впливу та пошуку альтернатив.

Розвиток життєвої компетентності дітей вимагає від сучасних педагогів відповідної професійної підготовки, яка має базуватися на поглибленні знань про сутність життєвої компетентності, на формуванні практичних умінь щодо реалізації дієвих механізмів творення власного життя людини, на розширенні професійних функцій у напрямку соціалізації, життєвого проектування й життєтворчості учнів. Соціальний педагог, за умов відповідної професійної підготовки, безперервної самоосвіти та професійного самовдосконалення, спрямованості на особистість дитини, високого рівня комунікативності й емпатійності, здатності будувати взаємодію 3 підлітками на основі діалогу, на нашу думку, здатен організувати та здійснювати соціально-педагогічний супровід процесу формування ключових життєвих компетенцій підлітків 3 відповідною результативністю (Євтух М. Б., Сердюк О. П., 2002, с. 85).

У ході дослідження виділено технології соціально-педагогічної діяльності, застосування яких у загальноосвітній школі, на нашу думку, не лише забезпечить вирішення широкого спектру соціально-педагогічних завдань, а й сприятиме формуванню життєвої компетентності підлітків, серед яких:

технології соціально-педагогічної підтримки і супроводу, мета яких полягає в організації продуктивної співпраці учнів, їх батьків та педагогів у напрямку формування ключових компетенцій дітей, пошуку оптимальних шляхів їх особистісного розвитку, у створенні атмосфери безпеки, захищеності й постійної підтримки на шляху всебічного розвитку дитини, ऑiі компетентнісного становлення;

технології життєвого проектування, які покликані сприяти визначенню особистістю траєкторій власної життєпобудови й особистісного розвитку, набуттю учнями практичного знання та здатності самостійного вирішення життєвих задач різної складності, досягненню своїх життєвих цілей, визначенню життєвої позиції, розбудові особистістю життєвого проекту, життєвої програми, планів (Срмаков І. Г., 2005, с. 279);

технології розробки та впровадження соціальних проектів, що покликані залучити підростаюче покоління до вирішення актуальних соціальних проблем, до суспільно значущої діяльності, надати можливість висловлювати власну точку 
зору на соціальні проблеми і впливати на результативність їх вирішення, закріпити впевненість молодого покоління у важливості їх участі, активності й небайдужості до проблем соціуму;

технології соціальної адаптації та реабілітації підлітків, які спрямовані на засвоєння підлітками суспільних норм поведінки й загальнолюдських цінностей, успішну соціалізацію кожного вихованця, гнучку адаптацію до різних життєвих обставин, створення умов творчого розвитку, самореалізації особистості підлітка, гідних й комфортних умов життя підлітків, соціальної реабілітації підлітків, що опинились у несприятливих умовах соціалізації, із обов'язковим врахуванням соціальним педагогом особистісних якостей підлітків, особливостей конкретних проблемних ситуацій, орієнтацією на «суб'єкт-суб'єктні» відносини (Заверико H. B., 2004, с. 83);

технології розвитку й стимулювання пізнавальної активності і творчих здібностей, що передбачають застосування у соціально-педагогічній практиці таких засобів, форм та методів роботи, які в змозі забезпечити активізацію внутрішніх ресурсів, задатків й здібностей, талантів та творчого потенціалу особистості підлітка і спрямувати їх на покращення процесу його соціалізації, навчальної успішності, пошук сфер самореалізації та самовдосконалення;

технології формування відповідального ставлення до здоров'я, покликані допомогти підліткам, які в силу вікових особливостей схильні до ризикованої поведінки, усвідомити значущість стану здоров'я у житті людини, цінність й важливість власного здоров'я та здоров'я оточуючих, а також сприяти виробленню відповідального ставлення особистості підлітка до збереження, зміцнення й примноження свого соціального, психічного й фізичного здоров'я;

технології попередження виникнення й розв'язання конфліктів, що мають на меті засвоєння підлітками таких актуальних в цей віковий період моделей безконфліктної поведінки, орієнтованої на результативну співпрацю та діалог, а також вироблення засобів конструктивного вирішення суперечливих ситуацій;

метод «рівний-рівному», який будується на передачі достовірної інформації що стосується важливих соціальних питань, сучасних тенденцій розвитку підліткового середовища, особистісних проблем шляхом довірливого спілкування в межах організованої (акції, тренінги) та неформальної роботи (спонтанне спілкування), яку проводять підготовлені підлітки й молоді люди (Безпалько O. B., 2009, с. 73).

інтерактивні технології соціально-педагогічної роботи 3 дітьми, які передбачають формування життєвих навичок учня через застосування комплексу проектних, ігрових й тренінгових технологій, i, таким чином, створюють атмосферу співробітництва й творчої взаємодії всіх учасників освітнього процесу під час моделювання реальних життєвих ситуацій, рольових ігор і практикумів задля розвитку життєвої компетентності учнів (Срмаков I. Г., 2005, с. 419);

технологія соціального партнерства, яка спрямована на об'єднання педагогічних зусиль та ресурсів всіх соціальних інститутів щодо формування конкурентоспроможної особистості, готової будувати нові продуктивні відносини з оточуючими, проявляти ініціативу, нести відповідальність за прийняті рішення; 
технологія соціально-педагогічного консультування, яка об'єднує інформаційні, профілактичні, корекційно-розвивальні засоби й потенціал консультаційної роботи соціального педагога 3 підлітками щодо їх мотивації до саморозвитку і самовдосконалення, пошуку життєвих авторитетів та орієнтирів, розмаїття видів діяльності для творчої самореалізації, здійснення продуктивної комунікації та створення мережі міжособистісних стосунків, вироблення близьких цілей та завдань на перспективу, побудови планів їх реалізації, можливостей та небезпек інтернет-ресурсів;

технологія організації соціальної практики учнів, яка орієнтується на вирішення таких соціально-педагогічних завдань, як формування соціальноправових компетенцій учнів шляхом їх залучення до суспільно значущої діяльності, розвиток комунікативної культури, сприяння успішній соціалізації і вироблення індивідуальних моделей законослухняної поведінки, формування умінь застосовувати знання у конкретних життєвих ситуаціях, допомога у визначенні професійного шляху і пошуку гідного місця у сучасному соціумі (Нечипоренко В. В., 2013, с. 130).

\section{Висновки}

Таким чином, розуміння сутності життєвої компетентності підлітків, використання соціально-педагогічного потенціалу загальноосвітнього навчального закладу, а також специфічна, компетентнісно-орієнтована професійна підготовка соціальних педагогів й використання ними у практичній роботі технологій соціально-педагогічної діяльності щодо розкриття та розвитку компетентнісного, життєтворчого потенціалу підлітків сприятиме успішній реалізації компетентнісного підходу в освіті, забезпечить розвиток ключових компетенцій для життя учнів, зокрема підлітків, які потребують особливої уваги 3 боку дорослих. Тому формування життєвої компетентності підлітків є надактуальним напрямом соціально-педагогічної роботи у сучасній школі.

Перспективами подальших досліджень вважаємо розробку навчальновиховного контенту професійної підготовки майбутніх соціальних педагогів у школі в напрямку роботи 3 підлітками щодо їх особистісного становлення й формування життєвої компетентності.

\section{Література}

Безпалько О.В. Соціальна педагогіка : схеми, таблиці, коментарі : навч. посібник. К. : Центр учбової літератури, 2009. 208 с.

Варецька О. В. Компетентність як набута гуманістична чеснота. Педагогіка формування творчої особистості у вищій $і$ загальноосвітній иколах. 2014, (36), 118126.

Євтух М. Б., Сердюк О. П. Соціальна педагогіка : Підручник. Київ : МАУП, 2002. 232 c.

Єрмаков І. Г., Пузіков Д. О. Проектне бачення компетентнісно спрямованої 12річної середньої школи. Запоріжжя : Центріон, 2005. 112 с.

Життєва компетентність особистості : від теорії до практики / За ред. І. Г. Єрмакова. Запоріжжя : Центріон, 2005. 640 с. 
Життєва компетентність особистості : науково-методичний посібник / За ред. Л. В. Сохань, І. Г. Єрмакова, Г. М. Несен. Київ : Богдана, 2003. 520 с.

Заверико Н. В. Теоретичні засади соціально-педагогічної технології роботи 3 підлітками. Науковий часопис НПУ імені М. П. Драгоманова. 2004, (2), 81 - 87.

Концепція реалізації державної політики у сфері реформування загальної середньої освіти «Нова українська школа» на період до 2029 року : затверджено розпорядженням Кабінету Міністрів України від 14 грудня 2016 р. №988-p. URL : http:// www.kmu.gov.ua/control/uk/cardnpd?docid=249613934 (дата звернення : 12.11.2017).

Кутішенко В. П. Вікова та педагогічна психологія (курс лекцій): Навч. посіб. Київ: Центр учбової літератури, 2010. 128 с.

Лещук Г. Вплив засобів масової інформації на процес соціалізації підлітків. Молодь і ринок. 2014, (3), 76 - 80.

Нечипоренко В. В. Системний розвиток навчально-реабілітаційного центру як відкритої інноваційної соціально-освітньої інституції : монографія. Запоріжжя: Видавництво Хортицького національного навчально-реабілітаційного багатопрофільного центру, 2013. 512 с.

Нищета В.А. Життєва компетентність особистості: до питання створення функціональної моделі. Педагогіка і психологія формування творчої особистості: проблеми і пошуки: зб. наук. пр. / за ред. Т. І.Сущенко. Запоріжжя. 2008, (51), 257 264.

Освіта осіб з інвалідністю в Україні : тематична національна доповідь / ред. кол. : О. А. Удод, В І. Бондар та ін. Чернівці : Букрек, 2010. 436 с.

Прашко О. В. Особливості розвитку соціальної компетентності підлітків. Освіта та розвиток обдарованої особистості. 2013, (11), 23 - 27.

Про освіту : Закон України від 05.09.2017 p. № 2145-19. URL : http://zakon3.rada.gov.ua/laws/show/2145-19 (дата звернення : 22.12.2017).

Савченко О. Ключові компетентності - інноваційний результат шкільної освіти. Рідна школа. 2011, (8-9), 4-8.

Сейко Н. А. Соціальна педагогіка. Курс лекцій. Житомир: Житомир. держ. пед.ун-тет, 2002. 260 с.

Хуторской А. В. Ключевые компетенции как компонент личностноориентированной парадигмы образования. Ученик в общеобразовательной школе. М. : ИОСО РАО, 2002, 135-157. 


\title{
ADOLESCENTS' LIVING COMPETENCY: ESSENCE AND FEATURES OF FORMATION IN THE CONDITIONS OF COMPREHENSIVE EDUCATIONAL INSTITUTION
}

\author{
Dariya Velykzhanina, post-graduate student, Department of Pedagogy and \\ Pedagogical Excellence, Melitopol State Pedagogical University \\ named after Bogdan Khmelnytsky, Melitopol, Ukraine \\ darya.velik@ukr.net
}

\begin{abstract}
The article highlights the priority of implementation and conceptual ideas of a competent approach to education in Ukraine. The topicality of forming the vital competence of the younger generation in the conditions of modernity, which is a necessity of development of a fully developed personality, a responsible, independent, competent citizen as a member of a civilized society, is substantiated. The purpose of the article is to determine the essence of the adolescents' life competence and the features of its formation in a general secondary school. The essence of the concepts of «competence», «vital competence», peculiarities of personal and social development of adolescents taking into account modern realities of a society's life are analyzed with the help of general scientific methods of analysis, synthesis, generalization and systematization of pedagogical sciences. The specifics of social and pedagogical activity with this category of children are investigated. The result of scientific research is an attempt to reveal the essence of the definition of "adolescents' life competence» as a deliberated complex of personal characteristics and abilities in terms of manifestation of responsible, independent and socially mature behavior within their age development; definition of priority and secondary life goals and perspectives with the development of variational plans for their achievement; carrying out of one's own life in the context of continuous self-improvement as a key segment of personal development in general. The socio-pedagogical potential of a comprehensive educational institution is outlined in order to create comfortable conditions for the development and incipience of the individual of each student, the formation of key competencies for the adolescents' life. There was determined the necessity of concentration of pedagogical efforts and organization of social-pedagogical work with adolescents at school in the following directions as: promotion of their positive socialization; formation of the need for continuous self-education, self-realization in various spheres of life, ability to choose goals, to develop plans for their achievement, ability to solve life problems of varying complexity; the development of critical thinking, autonomy, competitiveness, social activity, key life competencies. The attention is focused on the need for professional training of pedagogical staff, in particular, social pedagogues, for working with adolescents in the context of the orientation of a modern school on the development of the vital competence of the child's personality. The technologies of socio-pedagogical activity with adolescents in school are highlighted, which, in our opinion, will promote both the formation of the competence of the younger generation and the successful implementation of the competence approach in education in general.
\end{abstract}


Key words: competence; life competence; adolescent; comprehensive educational institution; competence approach to education; socio-pedagogical activity; professional competence of social pedagogues.

\section{References}

Bezpalko, O. V. (2009). Socialjna pedaghoghika : skhemy, tablytsi, komentari : navch. posibnyk [Social pedagogy : diagrams, tables, comments : textbook]. K. : Centr uchbovoi literatury. [in Ukrainian].

Jermakov, I. Gh. (2005). Zhyttjeva kompetentnistj osobystosti : vid teoriji do praktyky [The vital competence of the individual: from theory to practice]. Zaporizhzhja : Centrion. [in Ukrainian].

Jermakov, I. Gh., \& Puzikov, D. O. (2005). Proektne bachennja kompetentnisno sprjamovanoji 12-richnoji serednjoji shkoly [A project vision of a competent 12-year high school]. Zaporizhia, Ukraine. [in Ukrainian].

Jevtukh, M. B., Serdjuk O. P. (2002). Socialjna pedaghoghika : Pidruchnyk. [Social pedagogy: Textbook]. Kyiv, Ukraine : MAUP. [in Ukrainian].

Khutorskoj, A. V. (2002). Kljuchevie kompetencyy kak komponent lychnostnooryentyrovannoj paradyghmi obrazovanyja. Uchenyk $v$ obshheobrazovateljnoj shkole [Key competencies as a component of a person-oriented educational paradigm]. M. : YOSO RAO. [in Russian].

Koncepcija realizaciji derzhavnoji polityky u sferi reformuvannja zaghaljnoji serednjoji osvity «Nova ukrajinsjka shkola» na period do 2029 roku. (2016). [Concept of realization of state policy in the sphere of general secondary education reforming «New Ukrainian school» for the period up to 2029]. Order of the Cabinet of Ministers of Ukraine dated December 14, 2016, no. 888-r. Retrieved from http://www.kmu.gov.ua/control/uk/ cardnpd?docid=249613934 [in Ukrainian].

Kutishenko, V. P. (2010). Vikova ta pedaghoghichna psykhologhija (kurs lekcij): Navch. posib. [Age and pedagogical psychology (course of lectures): Teaching manual]. Kyiv, Ukraine : Centr uchbovoji literatury. [in Ukrainian].

Leshhuk, Gh. (2014). Vplyv zasobiv masovoji informaciji na proces socializaciji pidlitkiv [Influence of the mass media on the process of adolescents' socialization]. Molodj i rynok. (3). [in Ukrainian].

Nechyporenko, V. V. (2013). Systemnyj rozvytok navchaljno-reabilitacijnogho centru jak vidkrytoji innovacijnoji socialjno-osvitnjoji instytuciji : monoghrafija. [System development of a training and rehabilitation center as an open innovation social and educational institution: a monograph]. Zaporizhia, Ukraine: Vydavnyctvo Khortycjkoho nacionaljnoho navchaljno-reabilitacijnoho baghatoprofiljnoho centru. [in Ukrainian].

Nyshheta, V. A. (2008). Zhyttjeva kompetentnistj osobystosti: do pytannja stvorennja funkcionaljnoji modeli [The vital competence of the individual: the question of creating a functional model]. Pedaghoghika i psykhologhija formuvannja tvorchoji osobystosti: problemy i poshuky: zb. nauk. pr. / za red. T. I. Sushhenko. Zaporizhzhja. (51). [in Ukrainian]. 
Prashko, O. V. (2013). Osoblyvosti rozvytku socialjnoji kompetentnosti pidlitkiv [Features of development of adolescents' social competence].Osvita ta rozvytok obdarovanoji osobystosti.(11). [in Ukrainian].

Pro osvitu : Zakon Ukrajiny vid 05.09.2017. no. 2145-19. [About education : Law of Ukraine dated September 5, 2017, no. 2145-19]. Retrieved from http://zakon3.rada.gov.ua/laws/show/2145-19 [in Ukrainian].

Savchenko, O. (2011). Kljuchovi kompetentnosti - innovacijnyj rezuljtat shkiljnoji osvity [Key competencies are an innovative result of school education]. Ridna shkola. $(8-9)$. [in Ukrainian].

Sejko, N. A. (2002). Socialjna pedaghoghika. Kurs lekcij [Social pedagogy. Course of lectures]. Zhytomyr: Zhytomyr. derzh. ped.un-tet. (ukr).

Sokhanj, L. V., Jermakova, I. Gh., Nesen, Gh. M. (Eds.). (2003). Zhyttjeva kompetentnistj osobystosti : naukovo-metodychnyj posibnyk [Life competence of the person: scientific and methodical manual]. Kyiv, Ukraine: Bohdana. [in Ukrainian].

Udod, O. A., Bondar, V. I. (Eds.). (2010). Osvita osib z invalidnistju v Ukrajini : tematychna nacionaljna dopovidj [Education for people with disabilities in Ukraine: thematic national report]. Bukrek. [in Ukrainian].

Varecjka, O. V. (2014). Kompetentnistj jak nabuta ghumanistychna chesnota. [Competence as acquired humanistic virtue]. Pedaghoghika formuvannja tvorchoji osobystosti u vyshhij i zaghaljnoosvitnij shkolakh. (36). [in Ukrainian].

Zaveryko, N. V. (2004). Teoretychni zasady sotsialno-pedahohichnoi tekhnolohii roboty z pidlitkamy [Theoretical foundations of social-pedagogical technology of work with adolescents]. Naukovyi chasopys NPU imeni M. P. Drahomanova. (2). [in Ukrainian]. 
